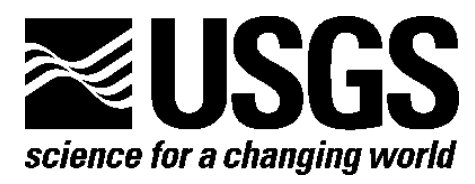

\title{
Publications of the Volcano Hazards Program 2009
}

By Manuel Nathenson

Open-File Report 2011-1047

U.S. Department of the Interior

U.S. Geological Survey 


\section{U.S. Department of the Interior \\ KEN SALAZAR, Secretary}

\section{U.S. Geological Survey \\ Marcia K. McNutt, Director}

U.S. Geological Survey, Reston, Virginia: 2011

For product and ordering information:

World Wide Web: http://www.usgs.gov/pubprod

Telephone: 1-888-ASK-USGS

For more information on the USGS-the Federal source for science about the Earth, its natural and living resources, natural hazards, and the environment:

World Wide Web: http://www.usgs.gov

Telephone: 1-888-ASK-USGS

Suggested citation:

Nathenson, Manuel, 2011, Publications of the Volcano Hazards Program 2009: U.S. Geological Survey Open-File Report 2011-1047, 10 p. [http://pubs.usgs.gov/of/2011/1047/].

Any use of trade, product, or firm names is for descriptive purposes only and does not imply endorsement by the U.S. Government.

Although this report is in the public domain, permission must be secured from the individual copyright owners to reproduce any copyrighted material contained within this report. 


\title{
Publications of the Volcano Hazards Program 2009
}

\author{
By Manuel Nathenson
}

The Volcano Hazards Program of the U.S. Geological Survey (USGS) is part of the Geologic Hazards Assessments subactivity as funded by congressional appropriation. Investigations are carried out in the USGS and with cooperators at the Alaska Division of Geological and Geophysical Surveys, University of Alaska Fairbanks Geophysical Institute, University of Hawaii Manoa and Hilo, University of Utah, and University of Washington Geophysics Program. This report lists publications from all these institutions.

Only published papers and maps are included here; numerous abstracts presented at scientific meetings are omitted. Publications dates are based on year of issue, with no attempt to assign them to fiscal year. 


\section{Volcano Hazards Bibliography 2009}

Albersheim, Steven, and Guffanti, Marianne, 2009, The United States national volcanic ash operations plan for aviation, in Prata, A.J., and Tupper, A., eds., Aviation hazards from volcanoes: Natural Hazards, v. 51, p. 275-285.

Battaglia, M., and Hill, D.P., 2009, Analytical modeling of gravity changes and crustal deformation at volcanoes: The Long Valley caldera, California, case study, in Gudmundsson, Agust, Acocella, Valerio, and Vinciguerra, Sergio, eds., Understanding stress and deformation in active volcanoes: Tectonophysics, v. 471, p. 45-57.

Battaglia, Maurizio, Poland, Michael, and Tizzani, Pietro, 2009, Volcano geodesy: SciTopic, Elsevier Publishing, available at http://www.scitopics.com/Volcano_geodesy.html.

Carn, S.A., Pallister, J.S., Lara, L., Ewert, J.W., Watt, S., Prata, A.J., Thomas, R.J., and Villarosa, G., 2009, The unexpected awakening of Chaitén volcano, Chile: Eos Transactions American Geophysical Union, v. 90, p. 205-206.

Chouet, Bernard, 2009, Nonlinear processes in volcanoes, in Meyers, R.A., ed., Encyclopedia of complexity and systems science: New York, Springer, v. 10, p. 9872-9899.

Clague, D.A., and Calvert, A.T., 2009, Postshield stage transitional volcanism on Mahukona Volcano, Hawaii: Bulletin of Volcanology, v. 71, p. 533-539.

Dalton, M.P., Watson, I.M., Nadeau, P.A., Werner, Cynthia, Morrow, William, and Shannon, J.M., 2009, Assessment of the UV camera sulfur dioxide retrieval for point source plumes: Journal of Volcanology and Geothermal Research, v. 188, p. 358-366.

DeNosaquo, K.R., Smith, R.B., and Lowry, A.R., 2009, Density and lithospheric strength models of the Yellowstone-Snake River Plain volcanic system from gravity and heat flow data, in Morgan, L.A., Cathey, H.E., and Pierce, K.L., eds., The track of the Yellowstone hotspot - What do neotectonics, climate indicators, volcanism, and petrogenesis reveal about subsurface processes?: Journal of Volcanology and Geothermal Research, v. 188, p. 108-127.

Diefenbach, A.K., Guffanti, Marianne, and Ewert, J.W., 2009, Chronology and references of volcanic eruptions and selected unrest in the United States, 1980-2008: U.S. Geological Survey Open-File Report 2009-1118, 85 p., available at http://pubs.usgs.gov/of/2009/1118/.

Dixon, J.P., and Power, J.A., 2009, The January 2006 volcanic-tectonic earthquake swarm at Mount Martin, Alaska, in Haeussler, P.J., and Galloway, J.P., eds., Studies by the U.S. Geological Survey in Alaska, 2007: U.S. Geological Survey Professional Paper 1760-D, 17 p., available at http://pubs.usgs.gov/pp/1760/d/.

Dixon, J.P., and Stihler, S.D., 2009, Catalog of earthquake hypocenters at Alaskan volcanoes: January 1 through December 31, 2008: U.S. Geological Survey Data Series 467, 88 p., data files, available at http://pubs.usgs.gov/ds/467/. 
Donnelly-Nolan, J.M., and Jensen, R.A., 2009, Ice and water on Newberry Volcano, central Oregon, in O’Connor, J.E., Dorsey, R.J., and Madin, I.P., eds., Volcanoes to vineyards-Geologic field trips through the dynamic landscape of the Pacific Northwest: Geological Society of America Field Guide 15, p. 81-90.

du Bray, E.A., Lund, Karen, Tilling, R.I., Denning, P.D., and DeWitt, Ed, 2009, Geochemical database for the Boulder batholith and its satellitic plutons, southwest Montana: U.S. Geological Survey Data Series 454, CD-ROM, available at http://pubs.usgs.gov/ds/454/.

Durant, A.J., Rose, W.I., Sarna-Wojcicki, A.M., Carey, S., and Volentik, A.C.M., 2009, Hydrometeor-enhanced tephra sedimentation: Constraints from the 18 May 1980 eruption of Mount St. Helens: Journal of Geophysical Research, v. 114, B03204, doi:10.1029/2008JB005756, 21 p.

Dzurisin, Daniel, Lisowski, Michael, and Wicks, C.W., 2009, Continuing inflation at Three Sisters volcanic center, central Oregon Cascade Range, USA, from GPS, leveling, and InSAR observations: Bulletin of Volcanology, v. 71, p. 1091-1110.

Dzurisin, Daniel, and Lu, Zhong, 2009, Volcano deformation and gravity workshop: Synopsis and outcomes: Eos Transactions of the American Geophysical Union, v. 90, p. 30.

Evans, W.C., Bergfeld, Deborah, McGimsey, R.G., and Hunt, A.G., 2009, Diffuse gas emissions at the Ukinrek Maars, Alaska: Implications for magmatic degassing and volcanic monitoring, in Evans, W.C., Harmon, R.S., and Wanty, R.B., eds., 2009, Special issue of expanded papers from 12th International Symposium on WaterRock Interaction (WRI-12): Applied Geochemistry, v. 24, p. 527-535.

Evans, W.C., Harmon, R.S., and Wanty, R.B., eds., 2009, Special issue of expanded papers from 12th International Symposium on Water-Rock Interaction (WRI-12): Applied Geochemistry, v. 24, p. 491-492.

Fabian, P., Garreau, R., Schneider, C., and Tilling, R., eds., 2009, 4th EGU Alexander von Humboldt Conference-The Andes: Challenge for Geosciences: Advances in Geosciences, v. 22, p. 1-189.

Fabian, P., Garreau, R., Schneider, C., and Tilling, R., 2009, Preface, in Fabian, P., Garreau, R., Schneider, C., and Tilling, R., eds., 4th EGU Alexander von Humboldt Conference-The Andes: Challenge for geosciences: Advances in Geosciences, v. 22, p. 1.

Faichney, I. D. E., Webster, J. M., Clague, D. A., Kelley, Chris, Appelgate, Bruce, and Moore, J. G., 2009, The morphology and distribution of submerged reefs in the Maui-Nui Complex, Hawaii: New insights into their evolution since the Early Pleistocene: Marine Geology, v. 265, p. 130-145.

Farrell, Jamie, Husen, Stephan, and Smith, R.B., 2009, Earthquake swarm and b-value characterization of the Yellowstone volcano-tectonic system, in Morgan, L.A., Cathey, H.E., and Pierce, K.L., eds., The track of the Yellowstone hotspot - What do neotectonics, climate indicators, volcanism, and petrogenesis reveal about subsurface processes?: Journal of Volcanology and Geothermal Research, v. 188, p. 260-276.

Fisher, M.A., Ruppert, N.A., White, R.A., Wilson, F.H., Comer, Drew, Sliter, R.A., and Wong, F.L., 2009, A distal earthquake cluster concurrent with the 2006 explosive eruption of Augustine Volcano, Alaska: Tectonophysics, v. 469, p. 25-36. 
Fiske, R.S., Rose, T.R., Swanson, D.A., Champion, D.E., and McGeehin, J.P., 2009, Kulanaokuaiki Tephra (ca. A.D. 400-1000): Newly recognized evidence for highly explosive eruptions at K̄lauea Volcano, Hawai'i: Geological Society of America Bulletin, v. 121, p. 712-728.

Fournier, Thomas, Freymueller, Jeff, and Cervelli, Peter, 2009, Tracking magma volume recovery at Okmok volcano using GPS and an unscented Kalman filter: Journal of Geophysical Research, v. 114, B02405, doi:10.1029/2008JB005837, 18 p.

França, Zilda, Forjaz, Victor, Tilling, Robert, Kuentz, David, Widom, Elizabeth, and Lago, Marceliano, 2009, Volcanic history of Pico and Faial Islands, Azores-An overview: Ponta Delgada, São Miguel, Azores, Portugal, Nova Gráfica, 270 p.

Greene, A.R., Garcia, M.O., and Orr, Tim, 2009, Time-series analysis of the Pu'u ' $\overline{\mathrm{O}}{ }^{‘} \overline{\mathrm{O}}-$ Kūpaianaha eruption (1983-2009), K̄̄llauea Volcano, Hawai‘i: Crustal processes, in Teaching petrology in the $21^{\text {st }}$ century: Bozeman, Montana State University, available at http://serc.carleton.edu/NAGTWorkshop/petrology/teaching_examples/35081.html.

Guffanti, Marianne, Mayberry, G.C., Casadevall, T.J., and Wunderman, Richard, 2009, Volcanic hazards to airports, in Prata, A.J., and Tupper, A., eds., Aviation hazards from volcanoes: Natural Hazards, v. 51, p. 287-302.

Haney, M.M., 2009, Infrasonic ambient noise interferometry from correlations of microbaroms: Geophysical Research Letters, v. 36, L19808, doi:10.1029/2009GL04017, 5 p.

Haney, M.M., van Wijk, Kasper, Preston, L.A., and Aldridge, D.F., 2009, Observation and modeling of source effects in coda wave interferometry at Pavlof Volcano: The Leading Edge, v. 28, p. 554-560.

Helz, R. T., 2009, Processes active in mafic magma chambers: The example of Kilauea Iki Lava Lake, Hawaii: Lithos, v. 111, p. 37-46.

Hutnak, M., Hurwitz, S., Ingebritsen, S.E., and Hsieh, P.A., 2009, Numerical models of caldera deformation: Effects of multiphase and multicomponent hydrothermal fluid flow: Journal of Geophysical Research, v. 114, B04411, doi:10.1029/2008JB006151, 11 p.

Ingebritsen, S.E., 2009, Book review of Tectonic faults - Agents of change on a dynamic Earth: Geofluids, v. 9, p.75-76.

Ingebritsen, S.E., Worden, Richard, and Yardley, B.W.D., 2009, Editorial: Geofluids, v. 9, p.1.

Iverson, R.M., 2009, Elements of an improved model of debris-flow motion, in Nakagawa, Masami, and Luding, Stefan, eds., Powders and Grains 2009; Proceedings of the 6th International Conference on Micromechanics of Granular Media: Melville N. Y., American Institute of Physics, p. 9-16.

Iverson, R.M., and Leveque, R.J., 2009, Modeling hazardous mass flows-Geoflows09: Mathematical and computational aspects of modeling hazardous geophysical mass flows: Seattle, Wash., March 9-11, 2009: Eos Transactions of the American Geophysical Union, v. 90, p. 201.

Jensen, R.A., Donnelly-Nolan, J.M., and Mckay, Daniele, 2009, A field guide to Newberry Volcano, Oregon, in O’Connor, J.E., Dorsey, R.J., and Madin, I.P., eds., Volcanoes to vineyards - Geologic field trips through the dynamic landscape of the Pacific Northwest: Geological Society of America Field Guide 15, p. 53-79. 
Jicha, B.R., Hart, G.L., Johnson, C.M., Hildreth, Wes, Beard, B.L., Shirey, S.B., and Valley, J.W., 2009, Isotopic and trace element constraints on the petrogenesis of lavas from the Mount Adams volcanic field, Washington: Contributions to Mineralogy and Petrology, v. 157, p. 189-207.

Jicha, B.R., Johnson, C.M., Hildreth, Wes, Beard, B.L., Hart, G.L., Shirey, S.B., and Singer, B.S., 2009, Discriminating assimilants and decoupling deep- vs. shallowlevel crystal records at Mount Adams using ${ }^{238} \mathrm{U}^{230}$ Th disequilibria and Os isotopes: Earth and Planetary Science Letters, v. 277, p. 38-49.

Kauahikaua, J., Howarth, Frank, and Hon, Ken, 2009, Lava tubes, in Gillespie, R.G., and Clague, D.A., eds., Encyclopedia of islands, v. 2 of Encyclopedias of the natural world: Berkeley, University of California Press, p. 544-549.

Larsen, J., Neal, C., Webley, P., Freymueller, J., Haney, M., McNutt, S., Schneider, D., Prejean, S., Schaefer, J., and Wessels, R., 2009, Eruption of Alaska volcano breaks historic pattern: Eos Transactions of the American Geophysical Union, v. 90, no. 20, p. 173-174.

Lechner, Peter, Mackersy, Keith, Tupper, Andrew, Patrick, Rebecca, Ruglys, Matt, Guffanti, Marianne, and Romero, Raul, 2009, Guidance for state volcano observatories: The International Airways Volcano Watch: International Civil Aviation Organization, 20 p., available at http://www.wovo.org/.

Logan, Matthew, and Iverson, R.M., 2009, Video documentation of experiments at the USGS debris-flow flume 1992-2006 (amended to include 2007-2009) (ver. 1.1): U.S. Geological Survey Open-File Report 2007-1315, videos, available at http://pubs.usgs.gov/of/2007/1315/.

Major, J.J., Crisafulli, C.M., Frenzen, Peter, and Bishop, John, 2009, After the disaster: The hydrogeomorphic, ecological, and biological responses to the 1980 eruption of Mount St. Helens, Washington, in O’Connor, J.E., Dorsey, R.J., and Madin, I.P., eds., Volcanoes to vineyards - Geologic field trips through the dynamic landscape of the Pacific Northwest: Geological Society of America Field Guide 15, p. 111134.

Major, J.J., Dzurisin, D., Schilling, S.P., and Poland, M.P., 2009, Monitoring lava-dome growth during the 2004-2008 Mount St. Helens, Washington, eruption using oblique terrestrial photography: Earth and Planetary Science Letters, v. 286, p. 243254.

Mandeville, C.W., Webster, J.D., Tappen, Christine, Taylor, B.E., Timbal, Adrian, Sasaki, Akira, Hauri, Erik, and Bacon, C.R., 2009, Stable isotopic and petrologic evidence for open-system degassing during the climactic and pre-climactic eruptions of Mt. Mazama, Crater Lake, Oregon: Geochimica et Cosmochimica Acta, v. 73, p. 29783012.

Mangan, Margaret, Miller, Thomas, Waythomas, Christopher, Trusdell, Frank, Calvert, Andrew, and Layer, Paul, 2009, Diverse lavas from closely spaced volcanoes drawing from a common parent: Emmons Lake Volcanic Center, Eastern Aleutian Arc: Earth and Planetary Science Letters, v. 287, p. 363-372.

Mastin, L.G., Guffanti, Marianne, Ewert, J.E., and Spiegel, Jessica, 2009, Preliminary spreadsheet of eruption source parameters for volcanoes of the world (ver. 1.2): U.S. Geological Survey Open-File Report 2009-1133, 25 p., available at http://pubs.usgs.gov/of/2009/1133/. 
Mastin, L.G., Guffanti, M., Servranckx, R., Webley, P., Barsotti, S., Dean, K., Durant, A., Ewert, J.W., Neri, A., Rose, W.I., Schneider, D., Siebert, L., Stunder, B., Swanson, G., Tupper, A., Volentik, A., and Waythomas, C.F., 2009, A multidisciplinary effort to assign realistic source parameters to models of volcanic ash-cloud transport and dispersion during eruptions, in Webley, Peter, and Mastin, Larry, eds., Improved prediction and tracking of volcanic ash clouds: Journal of Volcanology and Geothermal Research, v. 186, p. 10-21.

Mastin, L.G., Lisowski, Mike, Roeloffs, Evelyn, and Beeler, Nick 2009, Improved constraints on the estimated size and volatile content of the Mount St. Helens magma system from the 2004-2008 history of dome growth and deformation: Geophysical Research Letters, v. 36, L20304, doi:10.1029/2009GL039863, 4 p.

Matoza, R.S., Garcés, M.A., Chouet, B.A., D'Auria, Luca, Hedlin, M.A.H., De GrootHedlin, Catherine, and Waite, G.P., 2009, The source of infrasound associated with long-period events at Mount St. Helens: Journal of Geophysical Research, v. 114, B04305, doi:10.1029/2008JB006128, 38 p.

Mckay, Daniele, Donnelly-Nolan, J.M., Jensen, R.A., and Champion, D.E., 2009, The post-Mazama northwest rift zone eruption at Newberry Volcano, Oregon, in O’Connor, J.E., Dorsey, R.J., and Madin, I.P., eds., Volcanoes to vineyardsGeologic field trips through the dynamic landscape of the Pacific Northwest: Geological Society of America Field Guide 15, p. 91-110.

Montgomery-Brown, E.K., Segall, P., and Miklius, A., 2009, Kilauea slow slip events: Identification, source inversions, and relation to seismicity: Journal of Geophysical Research, v. 114, B00A03, doi:10.1029/2008JB006074, 20 p.

Morgan, L.A., Cathey, H.E., and Pierce, K.L., 2009, The track of the Yellowstone hotspot: Multi-disciplinary perspectives on the origin of the Yellowstone-Snake River Plain volcanic province, in Morgan, L.A., Cathey, H.E., and Pierce, K.L., eds., The track of the Yellowstone hotspot - What do neotectonics, climate indicators, volcanism, and petrogenesis reveal about subsurface processes?: Journal of Volcanology and Geothermal Research, v. 188, p. v-vi.

Morgan, L.A., Cathey, H.E., and Pierce, K.L., eds., 2009, The track of the Yellowstone hotspot - What do neotectonics, climate indicators, volcanism, and petrogenesis reveal about subsurface processes?: Journal of Volcanology and Geothermal Research, v. 188, p. 1-304.

Morgan, L.A., Shanks, W.C., and Pierce, K.L., 2009, Hydrothermal processes above a large magma chamber: Large hydrothermal systems and hydrothermal explosions in Yellowstone National Park: Geological Society of America Special Paper 459, $95 \mathrm{p}$.

Nakata, J.S., and Okubo, P.G., 2009, Hawaiian Volcano Observatory seismic data, January to December 2008: U.S. Geological Survey Open-File Report 2009-1251, 84 p., data files, available at http://pubs.usgs.gov/of/2009/1251/.

Nathenson, Manuel, 2009, Publications of the Volcano Hazards Program 2007: U.S. Geological Survey Open-File Report 2009-1071, 13 p., available at http://pubs.usgs.gov/of/2009/1071/.

Neal, Christina, Girina, Olga, Senyukov, Sergey, Rybin, Alexander, Osiensky, Jeffrey, Izbekov, Pavel, and Ferguson, Gail, 2009, Russian eruption warning systems for aviation: Natural Hazards, v. 51, p. 245-262. 
Neal, C.A., Larsen, J.F., and Schaefer, Janet, 2009, The July-August 2008 hydrovolcanic eruption of Okmok Volcano, Umnak Island, Alaska: Alaska Geological Society Newsletter, v. 39, no. 5, p. 1-3.

Okubo, P.G., and Clague, D.A., 2009, Earthquakes, in Gillespie, R.G., and Clague, D.A., eds., Encyclopedia of islands, v. 2 of Encyclopedias of the natural world: Berkeley, University of California Press, p. 240-244.

Park, Jaewoo, Morgan, J.K., Zelt, C.A., and Okubo, P.G., 2009, Volcano-tectonic implications of 3-D velocity structures derived from joint active and passive source tomography of the island of Hawaii: Journal of Geophysical Research, v. 114, B09301, doi:10.1029/2008JB005929, 19 p.

Pickering White, B.J., Smith, R.B., Husen, Stephan, Farrell, J.M., and Wong, Ivan, 2009, Seismicity and earthquake hazard analysis of the Teton-Yellowstone region, Wyoming, in Morgan, L.A., Cathey, H.E., and Pierce, K.L., eds., The track of the Yellowstone hotspot - What do neotectonics, climate indicators, volcanism, and petrogenesis reveal about subsurface processes?: Journal of Volcanology and Geothermal Research, v. 188, p. 277-296.

Pierce, K.L., and Morgan, L.A., 2009, Is the track of the Yellowstone hotspot driven by a deep mantle plume? - Review of volcanism, faulting, and uplift in light of new data, in Morgan, L.A., Cathey, H.E., and Pierce, K.L., eds., The track of the Yellowstone hotspot - What do neotectonics, climate indicators, volcanism, and petrogenesis reveal about subsurface processes?: Journal of Volcanology and Geothermal Research, v. 188, p. 1-25.

Pierson, T.C., Scott, W.E., Vallance, J.W., and Pringle, P.T., 2009, Eruption-related lahars and sedimentation response downstream of Mount Hood: Field guide to volcaniclastic deposits along the Sandy River, Oregon, in O’Connor, J.E., Dorsey, R.J., and Madin, I.P., eds., Volcanoes to vineyards - Geologic field trips through the dynamic landscape of the Pacific Northwest: Geological Society of America Field Guide 15, p. 221-236.

Pitcher, Lynette, Helz, R.T., Walker, R.J., and Piccoli, Philip, 2009, Fractionation of the platinum-group elements and Re during crystallization of basalt in Kilauea Iki Lava Lake, Hawaii: Chemical Geology, v. 260, p. 196-210.

Poland, M.P., Sutton, A.J., and Gerlach, T.M., 2009, Magma degassing triggered by static decompression at K̄lauea Volcano, Hawai'i: Geophysical Research Letters, v. 36, L16306, doi:10.1029/2009GL039214, 5 p.

Prejean, S.G., and Hill, D.P., 2009, Earthquakes, dynamic triggering of, in Meyers, R.A., ed., Encyclopedia of complexity and systems science: New York, Springer, v. 3, p. 2600-2621.

Pressling, N., Trusdell, F.A., and Gubbins, D., 2009, New and revised ${ }^{14} \mathrm{C}$ dates for Hawaiian surface lava flows: Paleomagnetic and geomagnetic implications: Geophysical Research Letters, v. 36, L11306, doi:10.1029/2009GL037792, 5 p.

Ramsey, D.W., 2009, Wizard Island, in Gillespie, R.G., and Clague, D.A., eds., Encyclopedia of islands, v. 2 of Encyclopedias of the natural world: Berkeley, University of California Press, p. 979-981.

Riker, J.M., Cashman, K.V., Kauahikaua, J.P., and Montierth, C.M., 2009, The length of channelized lava flows; insight from the 1859 eruption of Mauna Loa Volcano, Hawai'i: Journal of Volcanology and Geothermal Research, v. 183, p. 139-156. 
Schaefer, J.R., Cameron, C.E., and Nye, C.J., 2009, Historically active volcanoes of Alaska: Alaska Division of Geological and Geophysical Surveys Miscellaneous Publication 133, 1 plate, scale 1:3,000,000, available at http://www.dggs.dnr.state.ak.us/pubs/pubs?reqtype=citation\&ID=20181.

Sheppard, P.R., Ort, M.H., Anderson, K.C., Clynne, M.A., and May, E.M., 2009, Multiple dendrochronological responses to the eruption of Cinder Cone, Lassen Volcanic National Park, California: Dendrochronologia, v. 27, p. 213-221.

Sherman, L.S., Blum, J.D., Nordstrom, D.K., McCleskey, R.B., Barkay, T., and Vetriani, C., 2009, Mercury isotopic composition of hydrothermal systems in the Yellowstone Plateau volcanic field and Guaymas Basin sea-floor rift: Earth and Planetary Science Letters, v. 279, p. 86-96.

Sherrod, D.R., 2009, Hawaiian Islands, Geology, in Gillespie, R.G., and Clague, D.A., eds., Encyclopedia of islands, v. 2 of Encyclopedias of the natural world: Berkeley, University of California Press, p. 404-410.

Š́lený, Jan, Hill, D.P., Eisner, Leo, and Cornet, F.H., 2009, Non-double-couple mechanisms of microearthquakes induced by hydraulic fracturing: Journal of Geophysical Research, v. 114, B08307, doi:10.1029/2008JB005987, 15 p.

Simon, J.I., Vazquez, J.A., Renne, P.R., Schmitt, A.K., Bacon, C.R., and Reid, M.R., 2009, Accessory mineral U-Th-Pb ages and ${ }^{40} \mathrm{Ar} /{ }^{39} \mathrm{Ar}$ eruption chronology, and their bearing on rhyolitic magma evolution in the Pleistocene Coso volcanic field, California: Contributions to Mineralogy and Petrology, v. 158, p. 421-446.

Sisson, T.W., Kimura, J.-I., and Coombs, M.L., 2009, Basanite-nephelinite suite from early Kilauea: carbonated melts of phlogopite-garnet peridotite at Hawaii's leading magmatic edge: Contributions to Mineralogy and Petrology, v. 158, p. 803-829.

Sisson, T.W., and Vallance, J.W., 2009, Frequent eruptions of Mount Rainier over the last 2,600 years: Bulletin of Volcanology, v. 71, p. 595-618.

Smith, J.G., Dehn, Jonathan, Hoblitt, R.P., LaHusen, R.G., Lowenstern, J.B., Moran, S.C., McClelland, Lindsay, McGee, K.A., Nathenson, Manuel, Okubo, P.G., Pallister, J.S., Poland, M.P., Power, J.A., Schneider, D.J., and Sisson, T.W., 2009, Volcano monitoring, in Young, Rob, and Norby, Lisa, eds., Geological monitoring: Boulder, Colo., Geological Society of America, p. 273-305.

Smith, R.B., Jordan, Michael, Steinberger, Bernhard, Puskas, C.M., Farrell, Jamie, Waite, G.P., Husen, Stephan, Chang, Wu-Lung, and O'Connell, Richard, 2009, Geodynamics of the Yellowstone hotspot and mantle plume: Seismic and GPS imaging, kinematics, and mantle flow, in Morgan, L.A., Cathey, H.E., and Pierce, K.L., eds., The track of the Yellowstone hotspot - What do neotectonics, climate indicators, volcanism, and petrogenesis reveal about subsurface processes?: Journal of Volcanology and Geothermal Research, v. 188, p. 25-56.

Snedigar, S.F., and Cameron, C.C., 2009, Historically active volcanoes of Alaska reference deck: Alaska Division of Geological and Geophysical Surveys Information Circular 59, 52 playing cards, available at http://www.dggs.dnr.state.ak.us/pubs/pubs?reqtype=citation\&ID=20401.

Statz-Boyer, Patrick, Thurber, Clifford, Pesicek, Jeremy, and Prejean, Stephanie, 2009, High precision relocation of earthquakes at Iliamna Volcano, Alaska: Journal of Volcanology and Geothermal Research, v. 184, p. 323-332. 
Stovall, W.K., Houghton, B.F., Harris, A.J.L., and Swanson, D.A., 2009, A frozen record of density-driven overturn in lava lakes: the example of Kālauea Iki 1959: Bulletin of Volcanology, v. 71, p. 313-318.

Stovall, W.K., Houghton, B.F., Harris, A.J.L., and Swanson, D.A., 2009, Features of lava lake filling and draining and their implications for eruption dynamics: Bulletin of Volcanology, v. 71, p. 767-780.

Strukell, Erik, Einarsson, Pall, Geirsson, Halldor, Tryggvason, Eysteinn, Moore, J.G., and Olafsdottir, Rosa, 2009, Precision leveling and geodetic GPS observations performed on Surtsey between 1967 and 2002: Surtsey Research, v. 12, p. 37-45.

Swanson, Don, Wooten, Kelly, and Orr, Tim, 2009, Buckets of ash track tephra flux from Halema‘uma‘u, Hawai‘i: Eos Transactions American Geophysical Union, v. 46, p. 427.

Tilling, R.I., 2009, El Chichón’s “surprise” eruption in 1982-Lessons for reducing volcanic risk: Geofísica Internacional, v. 48, p. 3-19.

Tilling, R.I., 2009, Volcanism and associated hazards: the Andean perspective, in Fabian, P., Garreau, R., Schneider, C., and Tilling, R., eds., 4th EGU Alexander von Humboldt Conference-The Andes: Challenge for geosciences: Advances in Geosciences, v. 22, p. 125-137.

Tilling, R.I., 2009, Volcano hazards and early warning, in Meyers, R.A., ed., Encyclopedia of complexity and systems science: New York, Springer, v. 9, p. 9861-9872.

Tizzani, Pietro, Battaglia, Maurizio, Zeni, Giovanni, Atzori, Simone, Berardino, Paolo, and Lanari, Riccardo, 2009, Uplift and magma intrusion at Long Valley caldera from InSAR and gravity measurements: Geology, v. 37, p. 63-66.

Trusdell, F.A., 2009, Geology of the Mariana Islands, in Gillespie, R.G., and Clague, D.A., eds., Encyclopedia of islands, v. 2 of Encyclopedias of the natural world: Berkeley, University of California Press, p. 598-603.

van Manen, S.M., and Dehn, Jon, 2009, Satellite remote sensing of thermal activity at Bezymianny and Kliuchevskoi from 1993 to 1998: Geology, v. 37, p. 983-986.

Waite, G.P., and Moran, S.C., 2009, $V_{P}$ structure of Mount St. Helens, Washington, USA, imaged with local earthquake tomography: Journal of Volcanology and Geothermal Research, v. 182, p. 113-122.

Waitt, R.B., and Begét, J.E., 2009, Volcanic processes and geology of Augustine Volcano, Alaska: U.S. Geological Survey Professional Paper 1762, 78 p., 2 plates, scale 1:25,000, available at http://pubs.usgs.gov/pp/1762/.

Waythomas, C.F., Watts, Philip, Shi, Fengyan, and Kirby, J.T., 2009, Pacific Basin tsunami hazards associated with mass flows in the Aleutian arc of Alaska: Quaternary Science Reviews, v. 28, p. 1006-1019.

Webley, P.W., Dean, Kenneson, Bailey, J.E., Dehn, Jon, and Peterson, Rorik, 2009, Automated forecasting of volcanic ash dispersion utilizing Virtual Globes, in Prata, A.J., and Tupper, A., eds., Aviation hazards from volcanoes: Natural Hazards, v. 51, p. 345-361.

Webley, P.W., Dehn, J., Lovick, J., Dean, K.G., Bailey, J.E., and Valcic, L., 2009, Nearreal-time volcanic ash cloud detection: Experiences from the Alaska Volcano Observatory, in Webley, Peter, and Mastin, Larry, eds., Improved prediction and tracking of volcanic ash clouds: Journal of Volcanology and Geothermal Research, v. 186, p. 79-90. 
Webley, Peter, and Mastin, Larry, eds., 2009, Improved prediction and tracking of volcanic ash clouds: Journal of Volcanology and Geothermal Research, v. 186, p. 1-132.

Webley, Peter, and Mastin, Larry, 2009, Improved prediction and tracking of volcanic ash clouds, in Webley, Peter, and Mastin, Larry, eds., Improved prediction and tracking of volcanic ash clouds: Journal of Volcanology and Geothermal Research, v. 186, p. 1-9.

Webley, P.W., Stunder, B.J.B., and Dean, K.G, 2009, Preliminary sensitivity study of eruption source parameters for operational volcanic ash cloud transport and dispersion models-A case study of the August 1992 eruption of the Crater Peak vent, Mount Spurr, Alaska, in Webley, Peter, and Mastin, Larry, eds., Improved prediction and tracking of volcanic ash clouds: Journal of Volcanology and Geothermal Research, v. 186, p. 108-119.

Werner, C., Evans, W.C., Poland, M., Tucker, D.S., and Doukas, M.P., 2009, Long-term changes in quiescent degassing at Mount Baker Volcano, Washington, USA; evidence for a stalled intrusion in 1975 and connection to a deep magma source: Journal of Volcanology and Geothermal Research, v. 186, p. 379-386.

Wessells, Stephen, Lowenstern, Jake, and Venezky, Dina, 2009, Three short videos by the Yellowstone Volcano Observatory: U.S. Geological Survey Open-File Report 2009-1067, videos, available at http://pubs.usgs.gov/of/2009/1067/.

Widiwijayanti, C., Voight, B., Hidayat, D., and Schilling, S.P., 2009, Objective rapid delineation of areas at risk from block-and-ash pyroclastic flows and surges: Bulletin of Volcanology, v. 71, p. 687-703.

Wood, Nathan, and Soulard, Christopher, 2009, Variations in population exposure and sensitivity to lahar hazards from Mount Rainier, Washington: Journal of Volcanology and Geothermal Research, v. 188, p. 367-378.

Wood, N.J, and Soulard, C.E., 2009, Community exposure to lahar hazards from Mount Rainier, Washington: U.S. Geological Survey Scientific Investigations Report 2009-5211, 26 p., available at http://pubs.usgs.gov/sir/2009/5211/.

Wooten, K.M., Thornber, C.R., Orr, T.R., Ellis, J.F., and Trusdell, F.A., 2009, Catalog of tephra samples from K̄̄lauea's summit eruption, March-December 2008: U.S. Geological Survey Open-File Report 2009-1134, 26 p., database, available at http://pubs.usgs.gov/of/2009/1134/. 